\title{
Proses Pelaksanaan Roya Partial Pada Kantor Notaris
}

\author{
Gilang Bella Saputra1, I Made Dedy Priyanto²
}

1 Program Studi Magister (S2). Kenotariatan Fakultas Hukum Universitas Udayana, Bali-Indonesia, Email: gbellasaputra@gmail.com

2Fakultas Hukum Universitas Udayana, Email: dedy.priyanto23@yahoo.com

\begin{tabular}{l}
\hline Info Artikel \\
\hline Masuk : 1 September 2020 \\
Diterima : 11 November \\
2020 \\
Terbit : 15 Desember 2020 \\
Keywords : \\
Legal certainty, Partial \\
Roya, and notary \\
\\
\\
Corresponding Author: \\
Gilang Bella Saputra, \\
gbellasaputra@gmail.com \\
DOI: \\
10.24843/AC.2020.v05.i03.p03 \\
Kata kunci: \\
Partial, dan Notaris \\
\end{tabular}

\begin{abstract}
Roya Partial is a new legal institution formed, by providing an alternative settlement of repayment on a credit basis by paying off a portion of the credit that goes by pulling some of its collateral. "Article 2 of the Law No. 4-year 1996 on land rights and objects relating to the land", giving gaps in the performance of Roya Partial. Whereas article 1163 Civil Code states the rights of liabilities (mortgages) are not indivisible but bind all parts of the goods/moving objects. This can actually lead to a conflict of norms against both regulations. Based on that, formulated 2 problems 1) What is the legal basis of the implementation of a partial Roya, (2) How to process the implementation of Roya Partial in notary Office, the purpose of this research is to know the legal basis in the implementation of a partial roya and to know the process of implementing Roya Partial in notary office. The legal research method used is a normative legal research method of using a statutory approach, and a conceptual approach. Right to land that can be burdened by article 4 UUHT Jo article 25, 33, 39 UUPA namely: property rights, business rights, building rights, rights, houses and property rights in the unit and there are several procedures regarding the deletion of liabilities from the settlement to the execution of the force, then the method of implementation of a partial Roya notary office.
\end{abstract}


penelitian ini yakni untuk mengetahui dasar hukum dalam pelaksanaan Roya Partial dan untuk mengetahui segala proses pelaksanaan Roya Partial pada kantor Notaris. Metode penelitian hukum yang dipergunakan ialah metode penelitian hukum normatif mempergunakan pendekatan perundang-undangan, dan pendekatan konseptual. Hak Atas Tanah yang dapat dibebani Hak Tanggungan berdasarkan Pasal 4 UUHT Jo Pasal 25, 33, 39 UUPA yakni : Hak Milik, Hak Guna Usaha, Hak Guna Bangunan, Hak Pakai, Rumah Susun dan Hak Milik Atas Satuan Rumah Susun dan terdapat beberapa prosedur mengenai hapusnya hak tanggungan mulai dari pelunasan hingga eksekusi secara paksa, kemudian metode pelaksanaan roya partial pada kantor Notaris.

\section{Pendahuluan}

Pesatnya laju perekonomian lintas batas negara akan memberi dampak pula terhadap kemampuan sistem hukum pada suatu negara untuk menyelesaikan masalahrmasalah yang muncul. Masalah hukum yang dapat terjadi akibat dari perselisihan hubungan keperdataan antara pihak yang melakukan suatu transaksi atau melangsungkan suatu perjanjian.

Untuk memperkuat kedudukan para pihak serta memberi perlindungan dan kepastian hukum pihak-pihak dalam suatu perjanjian maka jabatan Notaris/PPAT memegang peran yang sangat penting. Seorang pejabat umum Notaris/PPAT juga harus memiliki kompetensi terhadap jabatannya. Oleh karena kewenangan seorang Notaris merupakan wewenang tersendiri dengan dasar hukumnya yakni Undang-Undang Nomor 2 Tahun 2014 Perubahan atas Undang-undang Nomor 30 Tahun 2004 tentang Jabatan Notaris.

Dari banyaknya permasalahan ditemukan di bidang kenotariatan, satu isu hukum yang menarik untuk dibahas yaitu mengangkat tentang proses dan prosedur pelaksanaan roya partial melalui kantor Notaris, karena didalam pelaksanaan penulis merasa bahwa proses peroyaan sertipikat secara partial atas jaminan dari hutang debitor suatu bank cukup mempunyai permasalahan dan dapat di argumentasikan secara hukum.

Penggunaan kata roya dapat dijumpai pada penjelasan umum "Undang-Undang No. 4 Tahun 1996 tentang Hak Tanggungan Atas Tanah Beserta Benda-Benda yang Berkaitan dengan Tanah"(UU Hak Tanggungan): "Pada buku tanah Hak Tanggungan yang bersangkutan dibubuhkan catatan mengenai hapusnya hak tersebut, sedang sertifikatnya ditiadakan. Pencatatan serupa, yang disebut pencoretan atau lebih dikenal sebagai (roya), dilakukan juga pada buku tanah dan sertifikat hak atas tanah yang semula dijadikan jaminan. Sertifikat hak atas tanah yang sudah dibubuhi catatan tersebut, diserahkan kembali kepada pemegang haknya". Menurut ketentuan Pasal 18 UU Hak Tanggungan, Pencoretan Hak Tanggungan merupakan suatu pelaksanaan penghapusan hak tanggungan yang dilaksanakan oleh pemberi Hak Tanggungan. 
Keberadaaan roya tidak lepas dari Hak Tanggungan. Hak ini diawali oleh Hak Tanggungan yang merupakan hak kebendaan yaitu suatu hak yang dapat diminta pertanggung jawaban oleh pengguna haknya dari pihak ketiga yang memiliki dan menguasai objek Hak Tanggungan ini, jika objek Hak Tanggungan itu dipindah alihkan oleh yang memberi Hak Tanggungan pertama. ${ }^{1}$

Pencoretan Hak Tanggungan adalah suatu kegiatan yang dilakukan oleh pemberi Hak Tanggungan (debitor) setelah Hak Tanggungan yang diberikan olehnya hapus, menurut ketentuan Pasal 18 UU Hak Tanggungan. ${ }^{2}$ Roya partial merupakan lembaga hukum yang baru terbentuk, dengan memberikan alternatif penyelesaian pembayaran kembali secara mengangsur suatu kredit dengan cara melunasi sebagian dari kredit yang berjalan dengan menarik sebagian dari jaminannya. Yang menjadi menarik adalah asas yang dimuat dalam Pasal 1163 KUH Perdata, Undang-Undang Hak Tanggungan (UUHT) memberi celah dapat dilaksanakannya Roya Partial. Pasal 2 UUHT menyatakan bahwa Hak Tanggungan mempunyai sifat tidak dapat dibagi-bagi, kecuali jika diperjanjikan dalam pembebanan Hak Tanggungan. Sesuai dengan Surat Edaran Menteri Negara Agraria Kepala BPN No. 600-1610-DIV tertanggal 16 Juni 1995 tentang penjelasan terhadap pelaksanaan Roya Partial disebutkan pada salah satu point bahwa hak atas tanah yang digunakan sebagai jaminan kredit dengan dibebani Hipotik/Credietverband, apabila telah dilunasi sebagian dapat dilakukan roya partial, sepanjang yang dibebani Hipotik/Credietverband terdiri dari beberapa bidang tanah. Apabila yang dibebani Hipotik/Credietverband hanya satu bidang tanah saja, tidak dapat dilakukan roya partial.

Pengembang dapat meminta roya partial, apabila pengembang telah mengangsur membayar kepada kreditor yang memberikan Kredit Konstruksi, dengan nominal yang sama besarnya dengan harga setiap hak atas tanah yang menjadi organ dalam suatu obyek Hak Tanggungan yang dilakukan pembebasan dari Hak Tanggungan itu, maka Hak Tanggungan tersebut hanya membebani sisa hutang yang belum dilunasi.

Sangat menarik proses dari pelaksanaan roya partial dimana debitor dapat mengambil/menarik jaminan atas hutang yang dijamin dengan beberapa agunan berupa tanah (sertipikat). Beberapa jaminan (lebih dari satu bidang) mempunyai nilai masing-masing sehingga jika salah satunya dilunasi maka dapat di roya/coret hak tanggungannya sehingga bisa di pergunakan untuk keperluan lain (dijaminkan di bank lain/dijual/disewakan). Hal ini memberikan peluang lain kepada debitor untuk mengembangkan asset melalui kesempatan kompromi terhadap ketentuan dari KUHPerdata pasal 1163 yang menyatakan Hak Tanggungan (Hipotek) tidak dapat dibagi-bagi tetapi mengikat seluruh bagian dari barang/benda bergerak itu. Jika di telaah ketentuan ini mungkin lebih pas berlaku untuk satuan rumah susun yang hendaknya wajib mengikuti ketentuan ini, karena pada prinsipnya akan sulit mengeksekusi terhadap bangunan yang berdiri diatas sebidang tanah.

\footnotetext{
${ }^{1}$ Sutan Remy Sjahdeini, (2010), Hak Tanggungan Asas-Asas, Ketentuan-Ketentuan Pokok dan Masalah Yang Dihadapi Oleh Perbankan (Suatu Kajian Mengenai Undang-Undang Hak Tanggungan), Cet. I, Alumni, Bandung, p.148.

${ }^{2}$ Bagus Pramana, (2011), Pembebanan Hak Tanggungan Terhadap Tanah Yang Diatasnya Ada Bangunan Milik Orang Lain, Universitas Diponegoro, p.61
} 
Pendapat yang sama tentang kemungkinan pelaksanaan roya partial dalam Hak Tanggungan juga diungkapkan oleh Boedi Harsono yang menyatakan: untuk kepentingan pemberi Hak Tanggungan (debitor) dapat diperjanjikan dan disebutkan dalam Akta Pemberian Hak Tanggungan yang bersangkutan bahwa pelunasan hutang yang dijaminkan dapat dilakukan dengan cara angsuran yang besarnya sama dengan nilai masing-masing satuan yang merupakan bagian dari obyek Hak Tanggungan tersebut. Bagian yang bersangkutan akan terbebas dari Hak Tanggungan yang semula membebaninya dan selanjutnya hanya membebani sisa obyeknya untuk menjamin sisa hutang yang belum dilunasinya, pengecualian ini disebut Roya Partial. Pengertian roya sendiri menurut J Satrio dalam bukunya adalah penghapusan catatan beban. ${ }^{3}$

Akan tetapi, pada prakteknya di kantor Notaris terutama yang berkerjasama dan menjadi rekanan Bank banyak melaksanakan terhadap jaminan atas pembelian tanah yang kemudian dibangun/dikembangkan perumahan oleh developer (pengembang) maupun perusahaan/perseorangan yang bidang usahanya jual beli tanah kavlingan yaitu dengan cara membeli dan menjaminkan tanah yang dibeli kemudian dilakukan pemecahan per masing-masing kavling, yang kemudian masing-masing kavling tersebut dipasang Hak Tangungan masing-masing (partial) sehingga jika ada pembeli yang membeli salah satu bidang kavling maka si debitor dalam hal ini pemberi Hak Tanggungan melakukan pelunasan secara partial yang kemudian di tarik jaminan/cabut jaminan kemudian dilaksanakan roya partial sebelum kavling tersebut di buatkan Akta Jual Beli kepada pembeli oleh PPAT.

Penelitian terdahulu yang berkaitan dengan penelitian ini, dilakukan oleh Novita Alviani pada tahun 2008. Penelitian tersebut lebih menekankan pada persyaratan yang telah disepakati oleh para pihak pada saat pembuatan Akta Pemberian Hak Tanggungan (APHT). Sedangkan penelitian ini lebih menekankan pada dasar hukum dan proses pelaksanaan roya partial pada kantor Notaris.

Merujuk pada latar belakang tersebut, maka dalam hal ini penulis tertarik untuk menulis sebuah paper yang berjudul "Proses Pelaksanaan Roya Partial Pada Kantor Notaris". Menjurus pada uraian latar belakang masalah yang telah dipaparkan dengan jelas di atas, maka dapat dirumuskan pokok-pokok permasalahan sebagai berikut: (1)Apakah yang menjadi dasar hukum dari pelaksanaan roya partial? (2)Bagaimanakah proses pelaksanaan Roya Partial pada Kantor Notaris ? Penulisan jurnal ini memuat tujuan umum dan juga tujuan khusus. Tujuan umum yang dimaksud, yakni untuk mengetahui dasar hukum dalam pelaksanaan roya partial. Tujuan khusus penelitian ini untuk mengetahui segala proses pelaksanaan Roya Partial pada kantor Notaris.

Manfaat Penelitian ini secara khusus ditujukan kepada Notaris, akademisi, mahasiswa, serta masyarakat, serta untuk menambah pengetahuan bagi penulis. Kemudian bagi notaris penelitian ini dapat dijadikan bahan dalam praktek terkait adanya pihak yang ingin melaksanakan roya partial karena menyangkut mengenai dasar hukum dilaksanakan roya partial dan prosedur pelaksanaan dari roya partial; bagi akademisi dan mahasiswa ini penelitian ini dapat menjadi bahan penunjang dan/atau untuk

${ }^{3}$ Rinaldi Dwi Permata, (2018), Roya Hak Tanggungan Yang Telah Dilunasi Oleh Debitur Dalam Hal Sertifikat Hak Tanggungan Yang Dikuasai Oleh Kreditur Hilang/Rusak, Universitas Sriwijaya, p.86 
menambah pengetahuan mengenai dasar hukum dilaksanakan roya partial dan prosedur pelaksanaan dari roya partial sesudah berlakunya Peraturan Pemerintah tentang pelaksanaan roya partial; penelitian ini memberi manfaat bagi masyarakat yang ingin memahami lebih dalam tentang roya partial agar dapat mengetahui mengenai prosedur pelaksanaan roya partial sesudah berlakunya Peraturan Pemerintah tentang pelaksanaannya dan bagi penulis dari penelitian ini dapat memberikan pengetahuan mengenai dasar hukum dilaksanakan roya partial dan prosedur pelaksanaan dari roya partial sesudah berlakunya Peraturan Pemerintah tentang pelaksanaan roya partial serta sebagai persyaratan dalam menyelesaikan studi magister kenotariatan Universitas Udayana.

\section{Metode Penelitian}

Penelitian ini mempergunakan metode penelitian hukum normatif. Metode penelitian hukum normatif ialah teknik menelaah atas peraturan perundang-perundangan yang melihat hierarki perundang-undangan secara vertikal, dan horizontal. ${ }^{4}$ Penggunaaan metode penelitian hukum normatif ini dikarenakan adanya norma konflik pada Pasal 2 Undang-Undang Hak Tanggungan (UUHT) memberi celah dapat dilaksanakannya Roya Partial dan KUHPerdata pasal 1163 yang menyatakan; Hak Tanggungan (Hipotek) tidak dapat dibagi-bagi tetapi mengikat seluruh bagian dari barang/benda bergerak itu. Metode pendekatan yang dipergunakan dalam membahas permasalahan yang diteliti, yakni menggunakan pendekatan perundang-undangan (the statute approach) dan pendekatan konseptual (conceptual approach). 5 Penulisan ini mempergunakan bahan hukum, yang terdapat bahan hukum primer dan sekunder serta bahan-bahan hukum lainnya. Bahan hukum primer terdiri atas UU No. 4 Tahun 1996 tentang Hak Tanggungan Atas Tanah Beserta Benda-Benda yang Berkaitan dengan Tanah dan Surat Edaran Menteri Negara Agraria Kepala BPN No. 600-1610DIV tertanggal 16 Juni 1995 tentang penjelasan terhadap pelaksanaan roya partial, selanjutnya bahan hukum sekunder mencangkup buku serta jurnal hukum yang sesuai terhadap permasalahan, dan bahan lainnya yang dikumpulkan dari internet. Teknik pengumpulan bahan hukum yang membantu menyelesaikan permasalahan ini ialah teknik sistematisasi bahan hukum primer serta teknik bola salju pada bahan hukum sekunder serta bahan hukum lainnya. Metode analisis bahan hukum penulisan ini ialah teknik deskriptif yang menjelaskan mengenai peristiwa atau kondisi hukum. ${ }^{6}$

\section{Hasil Dan Pembahasan}

\subsection{Pengertian Tentang Tanah, Hak Tanggungan dan Roya}

Menurut Jhon Salindeho, sederhananya Tanah merupakan benda yang dari sudut pandang masyarakat Indonesia memiliki nilai ekonomis. Tanah sebagai bagian dari bumi disebutkan dalam Pasal 4 ayat (1) Undang-undang No. 5 Tahun 1960 tentang Peraturan Dasar Pokok-pokok Agraria (UUPA) yaitu : atas dasar menguasai dari Negara sebagai yang dimaksud dalam Pasal 2 ditentukan adanya macam-macam hak

\footnotetext{
${ }^{4}$ Laurensius Arliman, S. (2018). Peranan Metodologi Penelitian Hukum Dalam Perkembangan Ilmu Hukum di Indonesia .Jurnal Soumatera Law Review, 1 (1).p. 118.

${ }^{5}$ Lexy J. Moleong, (2013), Metode Penelitian Kualitatif (Edisi Revisi), PT. Remaja Rosdakarya, Bandung, p. 186

${ }^{6}$ I Made Pasek Diantha. (2017). Metodelogi Penelitian Hukum Normatif dalam Justifikasi Teori Hukum. Jakarta:Prenada Media Group, p.153.
} 
atas permukaan bumi yang disebut tanah, yang dapat diberikan dan dapat pula dimiliki oleh orang-orang baik sendiri maupun bersama-sama dengan orang lain serta badan-badan hukum. ${ }^{7}$

Hak Atas Tanah yang dapat dibebani Hak Tanggungan berdasarkan Pasal 4 UUHT Jo Pasal 25, 33, 39 UUPA yakni:8 Hak Milik bersifat Hak turun temurun,yang dapat dimiliki seseorang terhadap tanah dan diserahkan kepada Warga Negara Indonesia tanpa terhalang atau adanya batasan waktu. Hak Guna Usaha yang diserahkan oleh negara kepada Badan Hukum yang berdirinya tidak bertentangan dengan hukum Indonesia juga berkedudukan di Indonesia dan atau Warga Negara Indonesia, dengan jangka waktu terlama yakni 35 (tiga puluh lima) tahun dan dapat diajukan perpanjangan waktu paling lama 25 (dua puluh lima) tahun. Apabila telah mencapai batas waktu yang telah diberikan atau dengan kata lain telah usai penguasa haknya dapat melakukan pembaruan Hak Guna Usaha terhadap tanah tersebut. Hak Guna Bangunan yang diserahkan oleh negara kepada Warga Negara Indonesia dan atau Badan Hukum yang berdirinya tidak bertentangan dengan hukum Indonesia juga berkedudukan di Indonesia, dengan jangka waktu terlama yakni 30 (tiga puluh) tahun dan dapat diajukan perpanjangan waktu paling lama 20 (dua puluh) tahun.

Apabila telah mencapai batas waktu selesai dapat dilakukan suatu pembaruan Hak atas tanah tersebut. Hak Pakai atas tanah Negara, sebagaimana dalam ketentuan yang berlaku Hak Pakai harus terdaftar dan bisa dipindah tangankan. Adapun jangka waktu yaitu 25 (dua puluh lima) tahun dan waktu perpanjangan paling lama 20 (duapuluh) tahun. Apabila telah mencapai batas waktu selesai dapat dilakukan pembaharuan Hak Pakai terhadap tanah yang sama tersebut.

Sarusun (Satuan rumah susun) yang berdiri di atas tanah Hak Pakai yang diserahkan oleh negara kepada Warga Negara Indonesia dan atau Badan Hukum yang berdirinya tidak bertentangan dengan hukum Indonesia juga berkedudukan di Indonesia, dengan jangka waktu terlama yakni 25 (dua puluh lima) tahun dan dapat diajukan perpanjangan waktu paling lama 20 (dua puluh) tahun apabila telah mencapai batas waktu yang telah diberikan atau dengan kata lain telah usai penguasa haknya dapat melakukan pembaruan Haknya. ${ }^{9}$

Berkaitan dengan hal tersebut Hak Tanggungan juga dapat dibebankan pada hak atas tanah termasuk dengan hal apapun yang berada diatas tanah tersebut dan tak terpisah-pisah dengan objek tersebut, dalam hal ini pembebanannya tertulis secara rinci dalam APHT mengenai objek tersebut. Seperti bangunan, tumbuhan dan lainlain.

Jika hal-hal yang berdiri diatas tanah tersebut bukan milik dari pemilik tanah, pembebanan hak mungkin dilakukan dengan penandatanganan sebagai bukti

Urip Santoso. (2010). Hukum Agraria \& Hakthak atas Tanah, Kencana Prenada Media Group, Jakarta, p. 10

8 Sri Soedewi Masjchoen, (2011), Pokok-pokok Hukum Jaminan dan Jaminan Perorangan, Badan Pembinaan Hukum Nasional Departewmen Kehakiman, p. 72

${ }^{9}$ Martha Novanditya, (2010), Jaminan Perlindungan Hukum Pada Perjanjian Kredit Perbankan, UniversitasSebelas Maret. p.32 
persetujuan oleh pemiliknya pada suatu APHT. Bersinggungan dengan hal tersebut, Hak tanggungan juga dapat terhapuskan, sebagaimana termaktub dalam Pasal 18 sampai dengan 19 Undang-Undang Nomor 4 Tahun 1996. Dari pasal tersebut arti dari hapusnya Hak Tanggungan yaitu Hak Tanggungan tidak berlaku lagi atau telah selesai.

Adapun penyebab hapusnya hak tanggungan (sering disebut roya), sebagai berikut : 10 1. Pembayaran hutang atau dilunasinya hutang oleh debitur,

2. Wanprestasi, yang berakibat teguran oleh kreditur untuk debitur memenuhi prestasinya. Teguran tersebut bersifat memaksa agar debitur segera melunasi utangnya dengan, Cedera janji yang dilakukan oleh Debitur.

3. Terjadinya cidera janji maka memungkinkan seorang kreditur untuk melaksanakan parate eksekusi yakni melelang barang objek jaminan tanpa mengikutsertakan pihak pengadilan. Hasil dari lelang tersebut akan dipergunakan untuk melunasi utangnya,

4. Sebagaimana pasal 224 HIR kemudian disertai pelelangan umum. Dalam hal ini kreditur mengikutsertakan pengadilan untuk kepentingan pelunasan utang. Kreditur mengajukan eksekusi ke pengadilan dengan menyertakan Sertifikat Hak Tanggungan. Dalam hal ini bukan berarti adanya gugatan.

5. Dilayangkannya gugatan oleh kreditur dikarenakan Debitur tidak mau melunasi utangnya atau hal lain yang menyebabkan cidera janji, yang selanjutnya disertai dengan putusan pengadilan yang jika memang terbukti debitur bersalah putusan tersebut dapat dieksekusi secara suka rela demi pelunasan utang.

6. Eksekusi secara paksa, dalam suatu keadaan dimana debitur enggan mengindahkan putusan pengadilan. Akan dilakukan eksekusi secara paksa berdasarkan putusan pengadilan tersebut yang juga melibatkan pelelangan umum kemudian hasilnya akan dipergunakan untuk membayar utang debitur.

\subsection{Dasar Hukum Pelaksanaan Roya Partial}

Berdasarkan atas ketentuan Pasal 2 ayat (2) Undang-undang No. 4 Tahun 1996 Tentang Hak Tanggungan sebagaimana berikut: “Apabila Hak Tanggungan dibebankan pada beberapa hak atas tanah, dapat diperjanjikan dalam Akta Pemberian Hak Tanggungan yang bersangkutan, bahwa pelunasan utang yang dijamin dapat dilakukan dengan cara angsuran yang besarnya sama dengan nilai masing-masing hak atas tanah yang merupakan bagian dari obyek Hak Tanggungan, yang akan dibebaskan dari Hak Tanggungan tersebut, sehingga kemudian Hak Tanggungan itu hanya membebani sisa obyek Hak Tanggungan untuk menjamin sisa utang yang belum dilunasi".

Merujuk pemaparan diatas kita tarik suatu hal bahwa memang pelaksanaan roya partial dapat dilakukan. Suatu pelaksanaaan kegiatan roya partial mengacu antara lain pada Surat Edaran Badan Pertanahan Nasional Nomor 600-1610 Tahun 1995 tentang Pelaksana Roya Partial (Sebagian), tertanggal 16 Juni 1995. Di dalam Surat Edaran tersebut antara lain sebagai berikut: 11

${ }^{10}$ Badriyah Harun, (2010), Tinjauan Yuridis Pemberian Kredit Dengan Hak Tanggungan di Bank BNI Kota Surabaya, Universitas Muhammadiyah Malang, P.65

${ }^{11}$ Juliana Amertha, (2013), Tinjauan Yuridis Mengenai Penghapusan Hak Tanggungan Roya Pada Bank Selaku Kreditor Yang Dilikuidasi Akibat Penggabungan Diri Dengan Bank Lain, Universitas Indonesia, p. 96 
2. Roya partial merupakan kelembagaan hukum baru, untuk memenuhi kebutuhan masyarakat, yang memungkinkan penyelesaian secara praktis terhadap bagian benda jaminan apabila telah dilunasi sebagian, sehingga dapat dipergunakan untuk keperluan lainnya. Dengan demikian, sungguhpun roya partial diatur dalam UURS (UU Rumah Susun), tetapi dapat diterapkan pula untuk menyelesaikan masalah roya partial di luar rumah susun.

3. Sehubungan dengan hal tersebut di atas, maka hak atas tanah yang dipergunakan sebagai jaminan kredit dibebani Hipotik/CV, apabila telah dilunasi sebagian, dapat dilakukan roya partial, sepanjang yang dibebani Hipotik/CV terdiri dari beberapa bidang tanah. Apabila yang dibebani Hipotik/CV hanya satu bidang tanah saja, tidak dapat dilakukan roya partial.

Aturan tentang prosedur pencoretan hak tanggungan termuat dalam Pasal 22 UndangUndang Hak Tanggungan yang menegaskan, :

1. Dengan terhapusnya suatu Hak Tanggungan, segera setelah itu Kantor Pertanahan wajib melaksanakan pencoretan terhadap buku tanah hak atas tanah berikut sertifikat tanah tersebut berkenaan dengan catatan Hak Tanggungan.

2. Setelah dilakukannya suatu penghapusan Hak Tanggungan, dapat diberlakukan penarikan sertifikat Hak Tanggungan bersamaan dengan buku tanah dinyatakan tidak berlaku lagi oleh Kantor Pertanahan.

3. Dalam suatu keadaan tidak dikembalikannya sertifikat ke Kantor Pertanahan, hal tersebut dicatat pada buku tanah Hak Tanggungan.

4. Pemohonan pencoretan dilakukan oleh yang memiliki kepentingan dengan menyertakan bukti sertifikat Hak Tanggungan dengan catatan dibuat oleh kreditor, berisikan keterangan bahwa Hak Tanggungan itu sudah hapus dikarenakan Hak Tanggungan yang dijadikan jaminan pelunasan utang telah terbayar lunas, atau keterangan dari kreditor yang menerangkan bahwa telah hapusnya Hak Tanggungan karena telah karena kreditor telah melepaskan Hak Tanggungan yang tersebut. 12

5. Pihak yang memiliki kepentingan boleh membuat pemohonan pelaksanaan pencoretan sebagaimana disebutkan sebelumnya kepada Ketua Pengadilan Negeri jika kreditor tidak bersedia memberikan pernyataan, pernyataan tersebut diajukan di daerah hukum dimana Hak Tanggungan tersebut terdaftar.

6. Jika permohonan perintah pencoretan timbul dari sengketa yang sedang diperiksa oleh Pengadilan Negeri lain, permohonan tersebut harus diajukan kepada Ketua Pengadilan Negeri yang memeriksa perkara yang bersangkutan.

7. Pemohonan pencoretan catatan Hak Tanggungan berdasarkan perintah Pengadilan Negeri diajukan kepada Kepala Kantor Pertanahan dengan melampirkan salinan penetapan atau putusan Pengadilan Negeri yang bersangkutan.

8. Pencoretan catatan Hak Tanggungan yang dilakukan kantor pertanahan menurut ketentuan perundang-undangan yang berlaku yaitu dalam waktu 7 (tujuh) hari kerja terhitung sejak diterimanya permohonan.

9. Jika pelunasan utang dilakukan dengan cara angsuran, hapusnya Hak Tanggungan pada bagian obyek Hak Tanggungan yang bersangkutan dicatat pada buku tanah

${ }^{12}$ Kartini Muljadi, (2011) , Kekuatan dan Kedudukan Akta Hak Tanggungan yang Dibuat oleh PPAT. Universitas Muhammadiyah Malang, P.121 
dan sertifikat Hak Tanggungan serta pada buku tanah dan sertifikat hak atas tanah yang telah bebas dari Hak Tanggungan yang semula membebaninya

Selain itu disebutkan juga dalam Pasal 18 ayat (1) UU Hak Tanggungan yang berkaitan dengan hapusnya Hak Tanggungan antara lain: Terhapusnya utang yang dijamin dengan Hak Tanggungan, Pemegang hak tanggungan melepaskan hak tanggungannya, Penetapan Ketua Pengadilan Negeri berkaitan dengan pembersihan Hak Tanggungan, Terhapusnya hak atas tanah yang dibebani Hak Tanggungan.

Sebagaimana diatur dalam Pasal 22 ayat (4), ayat (5), ayat (6), dan ayat (7) UndangUndang Hak Tanggungan, suatu pencoretan Hak Tanggungan pada dasarnya dapat dilakukan oleh debitor tersebut. Dapat disimpulkan bahwa menurut ketentuan Pasal 18 Undang-Undang Hak Tanggungan pencoretan Hak Tanggungan dilakukan setelah Hak Tanggungan yang diberikan oleh debitur terhapuskan. Dalam pelaksanaan pencoretan Hak Tanggungan, debitur dapat memanfaatkan semua fasilitas hukum yang ada termasuk permohonan perintah pencoretan kepada Ketua Pengadilan Negeri, dan dapat menggunakan semua alat bukti yang dibutuhkan untuk membuktikan bahwa Hak Tanggungan tersebut telah hapus.

\subsection{Proses Pelaksanaan Roya Partial pada Kantor Notaris.}

Roya pada umumnya dilaksanakan pada Kantor Badan Pertanahan, namun beberapa pihak (masyarakat) awam yang tidak paham proses dan persyaratan atau bank merekomendasi proses roya kepada kantor Notaris. Dalam pelaksanaannya hal tersebut juga tidak salah, karena kantor Notaris juga dapat melaksanakan proses pendaftaran tersebut ke Kantor Pertanahan (BPN). Didalam penulisan laporan ini lebih menekankan kepada pelaksanaan proses roya partsial di kantor notaris, karena secara hukum, sertipikat hak tanggungan yang di roya secara partial masih mempunyai ikatan hukum dengan perjanjian kredit yang menjadi perjanjian pokoknya (obligatoir), sedangkan hak tanggungan yang dibuat berdasarkan SKMHT dan APHT hanya merupakan perjanjian ikutan (accessoir). Karena hak tanggungan yang dipasang secara partial untuk Perjanjian Kredit tetap dibuat satu dengan menunjuk benda jaminan lebih dari sebidang, namun nilai hak tanggungannya masing-masing tidak menjadi satu, Akta Pemberian Hak Tanggungan (APHT) tetap dibuat satu, namun dipasang/didaftar secara partial pada Kantor Pertanahan (BPN), sehingga untuk royanya otomatis dapat dilaksanakan secara Partial/sebagian. ${ }^{14}$

Hal inilah yang membuat Bank sebagai lembaga pemberi pinjaman (penerima Hak Tanggungan) cederung dan bahkan mewajibkan peroyaan dilaksanakan pada Kantor notaris rekanan mereka, karena masih ada ikatan antara perjanjian kredit dan sebagian lagi hak tanggungan yang menjadi benda jaminan di Bank. Disamping itu pihak bank juga harus membuat suatu perjanjian perubahan perjanjian kredit atau Addendum

${ }^{13}$ Rahmat W. Hariyadi, (2017), Kajian Yuridis Pelaksanaan Roya Hak Atas Tanah Dalam Penjaminan Hak Tanggungan Berdasarkan Undang-Undang Nomor 4 Tahun 1996 tentang Hak Tanggungan Atas Tanah Beserta Benda-Benda Yang Berkaitan Dengan Tanah (Studi Pada Kantor Pertanahan Kota Surakarta), Universitas Sebelas Maret, p.77

14 Yunizar Ghazam Ilyas, (2015), Analisis Pelaksanaan Eksekusi Hak Tanggungan Pada Bank BRI di Kota Malang, Universitas Brawijaya, p.111 
terhadap perjanjian kredit sebelumnya yang menjadi landasan dari pendaftaran atau pemasangan hak tanggungan dari jaminan yang akan diroya secara partial.

Hak Tanggungan merupakan suatu Hak Jaminan yang dibebankan pada hak atas tanah sebagaimana dimaksud dalam Undang-Undang Nomor 5 Tahun 1960 tentang Peraturan Dasar Pokok-Pokok Agraria, berikut atau tidak berikut benda-benda lain yang merupakan satu kesatuan dengan tanah itu, untuk pelunasan hutang tertentu yang memberikan kedudukan yang diutamakan kepada kreditur tertentu terhadap kreditur-kreditur yang lain. Pemberiannya inheren atau mengikuti Perjanjian Pokok yaitu perjanjian yang menimbulkan suatu hubungan hukum hutang piutang yang dijaminkan pelunasannya 15

Perjanjian utang-piutang antara deibtur dan kreditur yang dibuat dihadapan seorang Pejabat Pembuat Akta Tanah (PPAT) adalah langkah awal atau syarat dalam penyaluran kredit dengan menggunakan Hak tanggungan sebagai jaminannya, yang tertuang dalam Akta Pemberian Hak Tanggungan (APHT). Sebagai awalan, debitur menyerahkan bukti kepemilikan hak atau sertifikat tanah yang akan dijadikan objek hak tanggungan sebagai bukti pelunasan utang. Kemudian untuk mengetahui tanah tersebut masih menanggung beban Hak Tanggungan atau tidak, PPAT bertugas memeriksa sertifikat hak atas tanah tersebut pada kantor pertanahan. jika tanah tersebut dinyatakan aman, barulah dibuatnya buku tanah Hak Tanggungan oleh pihak kantor pertanahan, mencatatkan tanah tersebut pada buku tanah, dan menyalin catatan tersebut dalam sertifikat Hak Atas Tanah milik debitur yang kemudian disimpan dikantor pertanahan. Kemudian dikeluarkannya Sertifikat Hak tanggungan oleh Kantor Pertanahan sebagai bukti bahwa benar adanya Hak tanggungan tersebut.

Kreditur menyimpan Sertifikat Hak Tanggungan beserta Sertifikat Hak Atas Tanah sebagai bukti jaminan pelunasan utang. Apabila debitur telah membayar lunas keseluruhan utangnya, barulah kreditor menyampaikan kepada Kantor Pertanahan untuk dilaksanakannya Roya. Dalam hal ini kreditor membuat surat permohonan yang berisikan keterangan bahwa segala utang yang dijamin pelunasannya dengan menggunakan hak tanggungan telah terhapuskan atau terlunasi, maka berdasarkan hal tersebut kreditur dengan ini memohon untuk dilaksanakannya roya atau pencoretan catatan beban hak tanggungan pada sertifikat tersebut. Surat permohonan tersebut juga terlampir asli sertifikat hak tanggungan dan asli sertifikat hak atas tanah. Setelah semua persyaratan terpenuhi, Kantor Pertanahan selanjutnya melakukan pencoretan pada catatan Hak Tanggungan tersebut atau biasa disebut melakukan roya. Dengan ini hapuslah Hak Tanggungan tersebut. Untuk sertifikat Hak Tanggungan akan ditarik oleh Kantor pertanahan dan sertifikat tersebut dinyatakan tidak berlaku, Sertifikat hak atas tanah akan dikembalikan oleh debitur jika seluruh proses dan prosedur pelaksanaan roya telah selesai. Dalam praktek pelaksanaan Roya Partial yang dilakukan di kantor Notaris biasanya melampirkan data-data sebagai berikut: Asli Sertipikat Hak Atas tanah, Asli Sertipikat Hak Tanggungan, Fotocopy KTP yang atas nama di Sertipikat Hak Atas Tanah, Fotocopy Kartu Keluarga yang atas nama di Sertipikat Hak Atas Tanah, Asli Surat Keterangan Lunas (sebagian) dari Bank yang

15Sri Soedewi Masjchoen, (2011), Pokok-pokok Hukum Jaminan dan Jaminan Perorangan, Badan Pembinaan Hukum Nasional Departemen Kehakiman, p. 72. 
menunjuk nomor sertipikat Hak Atas tanah dan Sertipikat Hak Tanggungan. ${ }^{16}$ Surat pengantar roya dari Bank yang ditujukan kepada Kepala Badan Pertanahan Nasional (BPN) kabupaten/Kota, Surat Kuasa dari pemilik sertipikat Hak Atas Tanah kepada salah satu Pegawai kantor Notaris yang pada intinya adalah surat kuasa substitusi untuk pendaftaran dan pengambilan jika royanya telah selesai pada kantor pertanahan.

Pada prakteknya di Kantor Notaris kelengkapan data untuk proses roya disiapkan dan didaftarkan oleh staf/pegawai Notaris, termasuk surat/map permohonannya. Setelah lengkap data-data yang dimaksud maka segera di daftarkan oleh staf Notaris ke Kantor Badan Pertanahan (BPN) Kabupaten/Kota. Lamanya proses pendaftaran hingga selesai memakan waktu paling cepat 7 (tujuh) hari kerja dan paling lama 30 (tiga puluh) hari kerja tergantung volume berkas yang masuk pada kantor pertanahan. ${ }^{17}$

Para Pengembang dapat meminta permohonan diselenggarakannya roya partial, hal ini dapat terjadi jika pengembang telah mengangsur pembayaran kepada pemberi kredit dengan nominal yang setara dengan nilai tiap-tiap hak atas tanah yang dijadikan objek Hak Tanggungan, dengan hal ini akan mengakibatkan hak tersebut terbebaskan dari pembebanannya atau dari hak tanggungannya. Hal ini berimbas pada Hak Tanggungan hanya membebani sebagian sisa utang yang belum terlunaskan. ${ }^{18}$

\section{Kesimpulan}

Dari uraian diatas maka dapat ditarik suatu kesimpulan yaitu :

Dasar hukum dari pemberlakuan adanya Roya Partial diatur dalam Pasal 2 ayat (2) Undang-undang No. 4 Tahun 1996 Tentang Hak Tangungan dan Surat Edaran Badan Pertanahan Nasional Nomor 600-1610 Tahun 1995 tentang Pelaksana Roya Partial (Sebagian), tertanggal 16 Juni 1995 Proses pelaksanaan Roya Partial di kantor Notaris dilaksanakan dengan cara pendaftaran pada kantor Pertanahan (BPN) yang di awali dengan melengkapi segenap data dan surat-surat pendukung. Peroyaan melalui kantor Notaris berkaitan dengan Hak Tanggungan Partial dalam prakteknya berhubungan dengan adanya perubahan perjanjian kredit atau take over kredit.

\section{Daftar Pustaka / Daftar Referensi}

\section{Buku :}

I Made Pasek Diantha. (2017). Metodelogi Penelitian Hukum Normatif dalam Justifikasi Teori Hukum. Jakarta: Prenada Media Group

\footnotetext{
${ }^{16}$ Desty Devita, (2011), Pelaksanaan Roya Partial Terhadap Jaminan Hak Tanggungan Pada PT. Bank Pembangunan Daerah Sumatra Selatan di Palembang, Universitas Diponogoro, p.121

${ }^{17}$ Fredi Bagus Kusumaning, (2016), Mekanisme Roya Hak Atas Tanah Yang Merupakan Agunan Debitor Atau Pada Perbankan Yang Dilelang Oleh Pejabat Lelang Karena Kreditnya Macet. Universitas IslamSultan Agung, p. 53

18 Sutan Remy Sjahdeini, 2010, Hak Tanggungan Asas-Asas Ketentuan-ketentuan Pokok dan Masalahnya Yang Dihadapi Oleh Perbankan, Alumni, Bandung, p.22.
} 
Lexy J. Moleong, (2013), Metode Penelitian Kualitatif (Edisi Revisi), PT. Remaja Rosdakarya, Bandung

Sri Soedewi Masjchoen, (2011), Pokok-pokok Hukum Jaminan dan Jaminan Perorangan, Badan Pembinaan Hukum Nasional Departewmen Kehakiman

Sutan Remy Sjahdeini, (2010), Hak Tanggungan Asas-Asas, Ketentuan-Ketentuan Pokok dan Masalah Yang Dihadapi Oleh Perbankan (Suatu Kajian Mengenai Undang-Undang Hak Tanggungan), Cet. I, Alumni, Bandung

Urip Santoso. (2010). Hukum Agraria \& Hak-hak atas Tanah, Kencana Prenada Media Group, Jakarta

\section{Skripsi atau Tesis :}

Badriyah Harun, (2010), Tinjauan Yuridis Pemberian Kredit Dengan Hak Tanggungan di Bank BNI Kota Surabaya, Universitas Muhammadiyah Malang.

Bagus Pramana, (2011), Pembebanan Hak Tanggungan Terhadap Tanah Yang Diatasnya Ada Bangunan Milik Orang Lain, Universitas Diponegoro

Desty Devita, (2011), Pelaksanaan Roya Partial Terhadap Jaminan Hak Tanggungan Pada PT. Bank Pembangunan Daerah Sumatra Selatan di Palembang, Universitas Diponogoro.

Fredi Bagus Kusumaning, (2016), Mekanisme Roya Hak Atas Tanah Yang Merupakan Agunan Debitor Atau Pada Perbankan Yang Dilelang Oleh Pejabat Lelang Karena Kreditnya Macet. Universitas Islam Sultan Agung.

Rinaldi Dwi Permata, (2018), Roya Hak Tanggungan Yang Telah Dilunasi Oleh Debitur Dalam Hal Sertifikat Hak Tanggungan Yang Dikuasai Oleh Kreditur Hilang/Rusak, Universitas Sriwijaya.

Martha Novanditya, (2010), Jaminan Perlindungan Hukum Pada Perjanjian Kredit Perbankan, Universitas Sebelas Maret.

Novita Alviani, (2008), Praktek Roya Partial Dalam Penjaminan Hak Tanggungan Menurut Undang-Undang Nomor 4 Tahun 1996 Tentang Hak Tanggungan Di Kota Semarang, Universitas Diponegoro

Juliana Amertha, (2013), Tinjauan Yuridis Mengenai Penghapusan Hak Tanggungan Roya Pada Bank Selaku Kreditor Yang Dilikuidasi Akibat Penggabungan Diri Dengan Bank Lain, Universitas Indonesia.

Kartini Muljadi, (2011), Kekuatan dan Kedudukan Akta Hak Tanggungan yang Dibuat oleh PPAT. Universitas Muhammadiyah Malang.

Rahmat W. Hariyadi, (2017), Kajian Yuridis Pelaksanaan Roya Hak Atas Tanah Dalam Penjaminan Hak Tanggungan Berdasarkan Undang-Undang Nomor 4 Tahun 1996 
tentang Hak Tanggungan Atas Tanah Beserta Benda-Benda Yang Berkaitan Dengan Tanah (Studi Pada Kantor Pertanahan Kota Surakarta), Universitas Sebelas Maret.

Yunizar Ghazam Ilyas, (2015), Analisis Pelaksanaan Eksekusi Hak Tanggungan Pada Bank BRI di Kota Malang, Universitas Brawijaya.

\section{Jurnal :}

Laurensius Arliman, S. (2018). Peranan Metodologi Penelitian Hukum Dalam Perkembangan Ilmu Hukum di Indonesia . Jurnal Soumatera Law Review, 1

\section{Peraturan Perundang- Undangan :}

Kitab Undang-Undang Hukum Perdata. Diterjemahkan dari Burgerlijk Wetboek (BW) Oleh Soedharyo Soimin, 2012, Sinar Grafika, Jakarta.

Undang-Undang Republik Indonesia Nomor 4 Tahun 1996 Tentang Hak Tanggungan Atas Tanah Beserta Benda-Benda yang Berkaitan Dengan Tanah..

Surat Edaran Menteri Negara Agraria Kepala BPN No. 600-1610-DIV tertanggal 16 Juni 1995 tentang penjelasan terhadap pelaksanaan Roya Partial. 